Acta vet. scand. 1964, 5, 209-216.

From the Department of Animal Husbandry, University of California, Davis, U.S.A.

\title{
THE EXCHANGE OF RADIOACTIVE MAGNESIUM IN THE TISSUES OF THE COW, CALF AND FETUS ${ }^{1}$ )
}

\author{
By \\ T. A. Rogers ${ }^{2}$ ), M. G. Simesen ${ }^{3}$ ), T. Lunaas ${ }^{4}$ ), and J. R. Luick.
}

Magnesium is the second most plentiful cation of the intracellular fluid in mammalian tissues and yet surprisingly little is known about its metabolism. The recent availability of the radioactive isotope, $\mathrm{Mg}^{28}$, has permitted kinetic and distribution studies in several species of intact animals (Rogers \& Mahan 1959; Aikawa et al. 1959; Lazzara et al. 1963) and in some isolated tissues (Rogers \& Mahan 1959; Gilbert et al. 1960; May \& Barnes 1960; Rogers 1961). The metabolism of magnesium in ruminants is of particular interest since these are the only animals in which a hypomagnesemic syndrome is commonly encountered. Several studies on the absorption and excretion of magnesium by ruminants have been carried out with the isotope (Field 1959; Simesen et al. 1962), but rather fewer tissue exchange studies have been conducted (Smith 1959; McApeese et al. 1961).

1) This investigation was supported by a grant from the U.S. Atomic Energy Commission (Contract AT (11-1)-34, no. 1.)

2) Present address: Pacific Biomedical Research Center, University of Hawaii, Honolulu, Hawaii.

3) On leave from the Royal Veterinary and Agricultural College, Copenhagen, Denmark; appointment supported by the International Co-operation Administration under the Visiting Research Scientists Program administered by the National Academy of Sciences of the United States of America.

4) Present address: The Royal Veterinary College, Oslo, Norway. 
This present study was undertaken to compare the distribution of $\mathrm{Mg}^{28}$ in calves and mature cows and to obtain some indication of the exchangeability of maternal extracellular magnesium with that of fetal tissues.

\section{METHODS}

Magnesium 28 is an isotope with a half-life of $21.3 \mathrm{hrs}$. emitting both $\gamma$ and $\beta$ rays. Other details of the isotope and its preparation for injection are described by Simesen et al. (1962).

Six normal calves were injected intravenously with carefully measured doses of $\mathrm{Mg}^{28}$ and killed in series of 0.5 hour, 1 hour, 3 hours, 6 hours, 12 hours and 24 hours. The ages and weights of these animals are listed in Table 1. A second series of animals comprised 4 mature, gravid cows which were also injected with $\mathrm{Mg}^{28}$ and killed at $0.5,1.0,3.0$ and 6.25 hours after injection. The cows had been condemned as tubercular reactors, but postmortem examination and cultures from the lymph glands did not reveal any infection. The vital statistics of these animals are also listed in Table 1.

T a b l e 1. Animals used.

\begin{tabular}{lclccc}
\hline & & & & $\begin{array}{c}\text { Isotope } \\
\text { dose } \\
\text { injected } \\
\text { cpm } \times 10^{5}\end{array}$ & $\begin{array}{c}\text { Time killed } \\
\text { after } \\
\text { injection } \\
\text { (hrs.) }\end{array}$ \\
\hline Calves & Animal \# & Breed & Wt. (kg) & & \\
& E 4 & Holst. & 45.0 & 276 & 0.5 \\
& E 2 & Holst. & 41.3 & 133 & 1.0 \\
& E 5 & Holst. & 35.9 & 276 & 3.0 \\
& E 3 & Jers. & 24.1 & 133 & 6.0 \\
& E 99 & Jers. & 21.6 & 60.67 & 12.0 \\
& E 1 & Holst. & 39.1 & 32.74 & 24.0 \\
& 1144 & Holst. & 695.4 & 1490 & 0.5 \\
& 1170 & Holst. & 641 & 952 & 1.0 \\
& 1163 & Holst. & 691 & 665 & 3.0 \\
& 1198 & Holst. & 582 & 2200 & 6.25 \\
\hline
\end{tabular}

After injection of the isotope all of the animals rested quietly. They were killed by shooting and were dissected immediately afterwards. The organs listed in Tables 2 and 3 were removed and weighed; duplicate or triplicate samples were taken for chemical and radiological analysis. After counting in a well-type scintillation counter, each tissue sample was ashed and analyzed 
for magnesium by flame photometry as described by Brown et al. (1952). The observed counting data were corrected for the decay of the isotope, and the specific activity of the magnesium in each sample was calculated.

The exchange of extracellular and intracellular magnesium can be described by the change of the relative specific activity. This is the specific activity of the tissue magnesium divided by that of the plasma magnesium; when this ratio is 1.0 , then equilibration is complete. It should be noted, however, that injection of the isotope inevitably raises the plasma magnesium concentration to a small degree and that this can lead to an uptake of extra magnesium by some tissues, as well as to the exchange under investigation. A gravimetrically insignificant extra uptake of magnesium after injection of the isotope by the kidney, for example, could suggest a more rapid exchange than is actually occurring and give a final value for the R.S.A. greater than 1.0.

\section{RESULTS AND DISCUSSION}

The main results are presented in Tables 2 and 3 ; the equilibration of certain tissues is also shown in Fig. 1. As would be expected from the larger number of animals, the calf data are more informative, but the adult cow data are generally consistent with them.

T a b l e 2. Relative specific activities in calf tissues following $\mathrm{Mg}^{28}$ injection.

\begin{tabular}{|c|c|c|c|c|c|c|}
\hline \multirow[b]{2}{*}{ Tissues } & \multicolumn{6}{|c|}{ Time killed after injection (hrs.) } \\
\hline & 0.5 & 1.0 & 3.0 & 6.0 & 12.0 & 24.0 \\
\hline Liver & .223 & .310 & .874 & 1.170 & 1.595 & 1.820 \\
\hline Kidney & .459 & .445 & .899 & 1.580 & 2.166 & 1.352 \\
\hline Heart & .208 & .235 & .729 & 1.203 & 1.406 & 1.644 \\
\hline Spleen & .105 & .133 & .341 & .577 & .790 & 1.072 \\
\hline Pancreas & .147 & .189 & .503 & .724 & .719 & 1.264 \\
\hline Thymus & - & .204 & .282 & .554 & .832 & 1.160 \\
\hline Brain & .094 & .264 & .818 & .747 & .660 & 1.760 \\
\hline Testis & .229 & .251 & .664 & .975 & - & - \\
\hline Muscle & .052 & .028 & .092 & .120 & .274 & .228 \\
\hline Omasum & .196 & .179 & .535 & .991 & & \\
\hline Abomasum & .185 & .312 & .336 & .724 & .953 & .964 \\
\hline Duodenum & .191 & .281 & - & 1.035 & .531 & 1.140 \\
\hline
\end{tabular}


T a b le 3. Relative specific activities of cow and fetal tissues following $\mathrm{Mg}^{28}$ injection. (Fetal tissues relative to maternal plasma $\mathrm{Mg}$ activity.)

\begin{tabular}{|c|c|c|c|c|c|}
\hline & \multirow[b]{2}{*}{ Tissues } & \multicolumn{4}{|c|}{ Time killed after injection (hrs.) } \\
\hline & & 0.5 & 1.0 & 3.0 & 6.25 \\
\hline \multicolumn{6}{|l|}{ Cows } \\
\hline & Liver & .154 & .131 & .590 & 1.222 \\
\hline & Kidney & .546 & .501 & 1.166 & 1.745 \\
\hline & Heart & .153 & .142 & .368 & 1.052 \\
\hline & Spleen & .148 & .148 & .413 & .702 \\
\hline & Pancreas & .094 & .134 & - & .679 \\
\hline & Brain & .016 & .001 & .041 & .086 \\
\hline & Muscle & .032 & .033 & .058 & .078 \\
\hline & Rum.-Ret. & .053 & .061 & .106 & .074 \\
\hline & Omasum & .131 & .059 & 一 & .229 \\
\hline & Abomasum & .112 & .139 & .506 & .793 \\
\hline & Jejunum & .101 & .140 & .086 & .826 \\
\hline & Udder & .238 & .211 & .529 & .828 \\
\hline \multicolumn{6}{|l|}{ Fetuses } \\
\hline & Liver & .004 & .018 & 0.17 & .051 \\
\hline & Kidney & .005 & .008 & - & .033 \\
\hline & Heart & .001 & .004 & $\mathbf{0}$ & .043 \\
\hline & Spleen & .005 & .001 & .010 & .010 \\
\hline & Pancreas & .001 & .001 & 0 & .009 \\
\hline & Muscle & $\mathbf{0}$ & .002 & .004 & .011 \\
\hline & Amniotic fluid & $\mathbf{0}$ & 0 & $\mathbf{0}$ & .003 \\
\hline & Allantoic fluid & 0 & 0 & .002 & .001 \\
\hline
\end{tabular}

Rogers \& Mahan (1959) reported that in the rat, tissues fall into two main groups with respect to the equlibration rate of intracellular and extracellular magnesium. The magnesium in liver, kidney and heart tissue exchanges rapidly and is in equilibrium with plasma $\mathrm{Mg}^{28}$ within 3 hours. In other tissues, typically skeletal muscle, brain, erythrocytes and testes, $20-30 \%$ of the intracellular magnesium exchanges rapidly but the remainder exchanges very slowly, with a turnover time of 25 hours. The tissues of the animals in the present experiments generally fell into the same two categories. In both the cows and the calves, however, the exchange was slower in each category than in the rat. As is shown in Fig. 1, the "fast" tissues did not equilibrate until about 6 hours after injection and the muscle magnesium took 12 hours to reach $25 \%$ equilibrium. Furthermore, it is 
Relative Specific Activity (R.S.A.) of Tissue Magnesium.

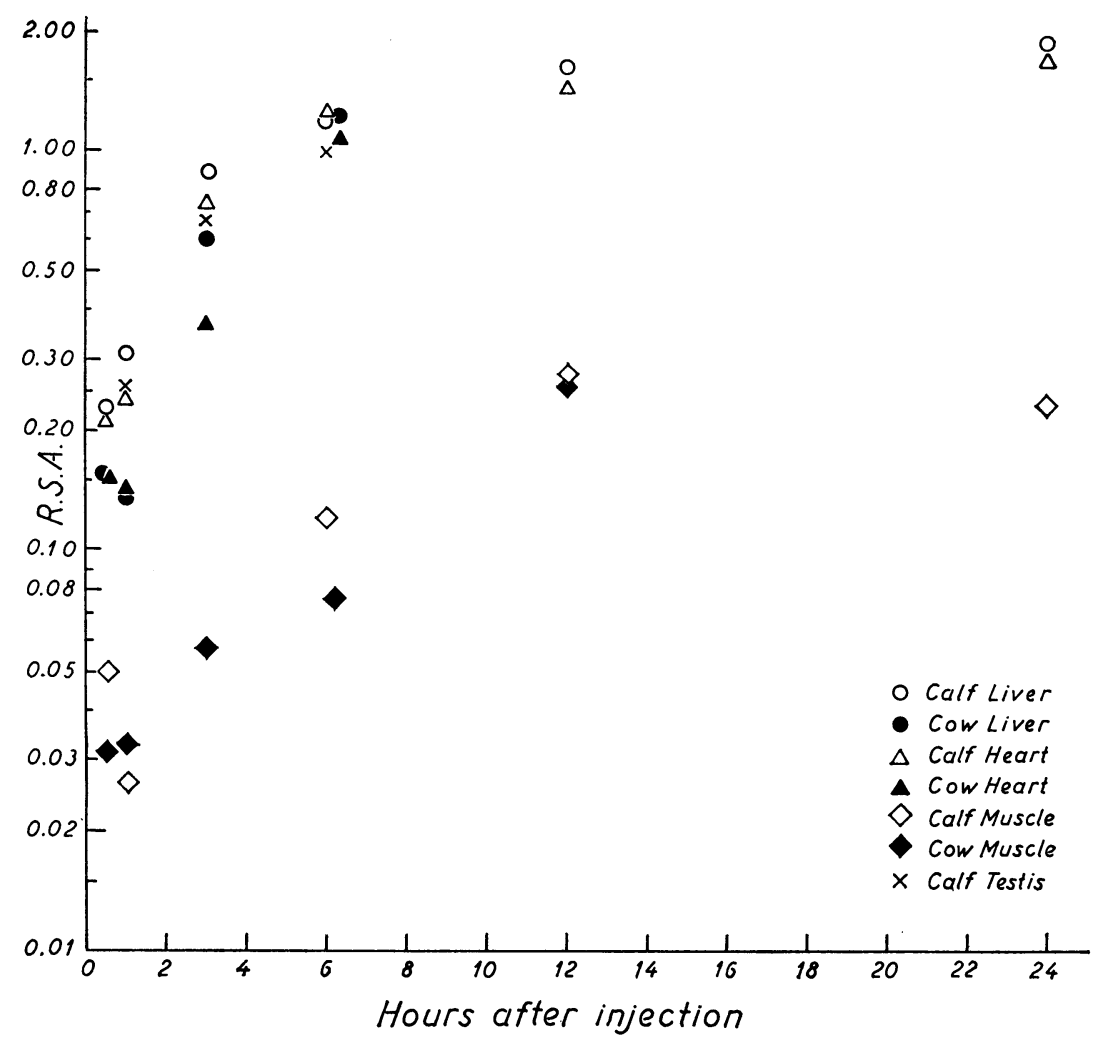

F i g. 1.

apparent that the initial fast component of exchange in muscle is slower in the cow and calf than in the rat; this component is slower to about the same extent as is the complete equilibration in the fast tissues.

One other important difference from the rat data was noted in the 4 male calves used; the equilibration of the testis magnesium was almost as rapid as that of the heart and liver (see Fig. 1). In the mature rat $(300 \mathrm{~g})$, the testis magnesium equilibrated as slowly as did skeletal muscle, but in $150 \mathrm{~g}$ rats the isotope exchanged somewhat more rapidly, reaching $70 \%$ equilibrium in 7 hours. The rapid exchange of isotope in the testes of our calves may be accounted for by their age of 6 weeks or less, which is physiologically younger than $150 \mathrm{~g}$ rats. 


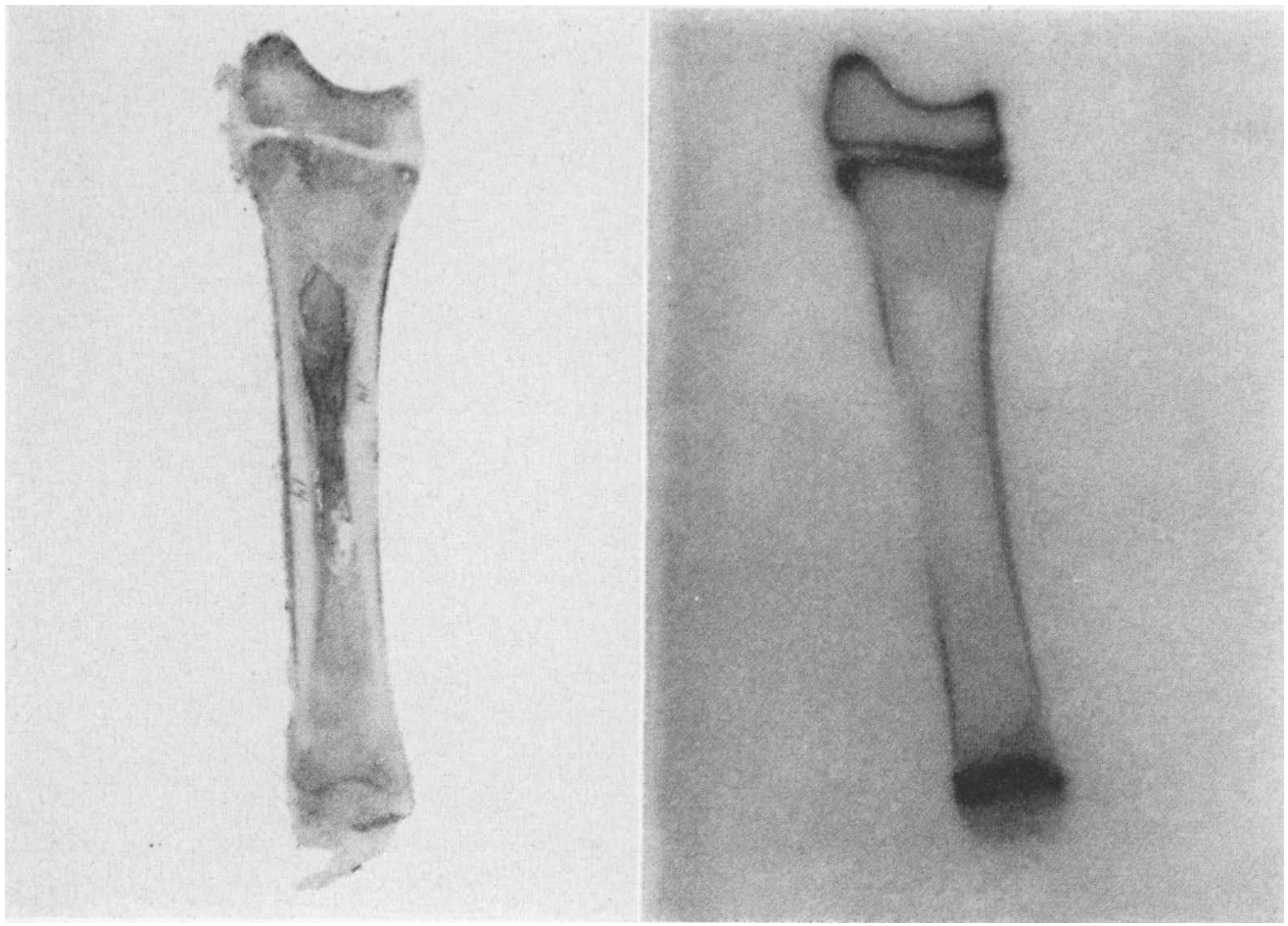

F i g. 2.

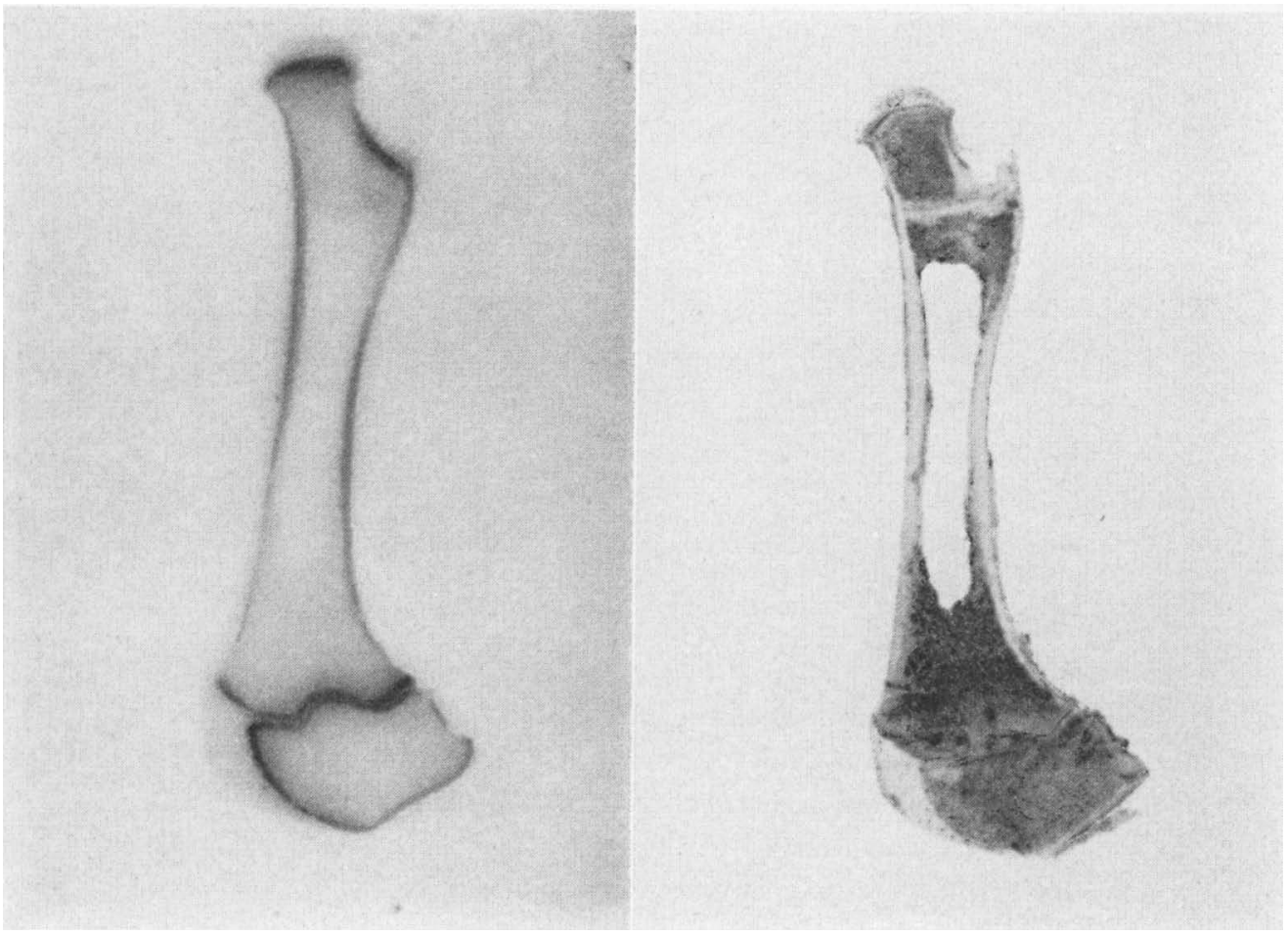

F i g. 3.

F ig s. 2 and 3 are autoradiograms and photographs made of tibia and femur of calves sacrificed 30 min.'s and $6 \mathrm{hrs}$. after injection of $\mathrm{Mg}^{28}$. 
The equilibration rates of the magnesium in several other tissues are shown in tables 2 and 3, and autoradiograms of tibia and femur are shown in figs. 2 and 3.

In the cows, the fetal tissue magnesium was in extremely slow exchange with the maternal plasma magnesium (see table 3 ). Even in the fetal liver and heart, the equilibration was less than $5 \%$ after 6 hours. The appearance of $\mathrm{Mg}^{28}$ in the "slow" fetal tissues and in the amniotic and allantoic fluids was virtually insignificant in the 6.25 hour period studied. The fetal bones showed the highest gross radioactivity, but the magnesium specific activity was as low as in the muscle at 6.25 hours. Unfortunately, technical difficulties during dissection of the cows prevented the recovery of fetal plasma, but a reasonable assumption is that the low activity of the fetal tissues resulted from a slow exchange of maternal and fetal plasma magnesium at the placenta. This would certainly be predicted from the work of Aikawa \& Bruns (1960) who showed that in gravid rabbits injected with $\mathrm{Mg}^{28}$, the maternal and fetal magnesium specific activities were not equilibrated until between 5 and 7 hours after injection.

\section{REFERENCES}

Aikawa, J. K.\& Bruns, P. D.: Placental transfer and fetal tissue uptake of $\mathrm{Mg}^{28}$ in the rabbit. Proc. Soc. exp. Biol. (N.Y.) 1960, 105, 95-98.

Aikawa, J. K., Rhoades, E. L., Harms, D. R. \& Reavdon, J. Z.: Magnesium metabolism in rabbits using $\mathrm{Mg}^{28}$ as a tracer. Amer. J. Physiol. 1959, 197, 99-101.

Brown, J. J., Lilleland, O. \& Jackson, R. K.: A line operated photomultiplier unit for measuring spectral emission in flame analysis. Amer. Soc. Hort. Sci. 1952, 59, 337-342.

Field, A. C.: Balance trials with magnesium 28 in sheep. Nature (Lond.) $1959,183,983$ only.

Gilbert, D. L. \& McGann, J.: Magnesium equilibrium in muscle. J. gen. Physiol. 1960, 43, 1103-1118.

Lazzara, R., Hyatt, K., Love, W. D., Cronvich, J. \& Burch, G. E.: Tissue distribution, kinetics and biologic half life of $\mathrm{Mg}^{28}$ in the dog. Amer. J. Physiol. 1963, 204, 1086-1094.

May, G. \& Barnes, B. A.: Comparison of magnesium and potassium efflux from incubated rat diaphragms. Amer. J. Physiol. 1960, 199, $246-250$.

McApeese, D. M., Bell, M. C. \& Forbes, R. M.: Magnesium 28 studies in lambs. J. Nutr. 1961, 74, 505-514.

Rogers, T. A.: The exchange of radioactive magnesium in erythrocytes of several species. J. cell. comp. Physiol. 1961, 57, 119-121. 
Rogers, T. A. \& Mahan, P. E.: The exchange of radioactive magnesium in the rat. Proc. Soc. exp. Biol. (N.Y.) 1959, 100, 235-239.

Simesen, M. G., Lunaas, T., Rogers, T. A.\& Luick, J. R.: The endogenous excretion of magnesium in cattle. Acta vet. scand. 1962, 3, 175 -184 .

Smith, R. H.: Calcium and magnesium metabolism in calves. Biochem. J. 1959, 71, 306-311.

\section{SUMMARY}

Calves and pregnant cows were injected with tracer doses of radioactive magnesium and killed at intervals. The pattern of exchange of the isotope with intracellular magnesium in various tissues was broadly similar to that reported for other species except that the equilibration rate was much slower than in the rat. An exception was that the testis magnesium in the 6 week old calves used exchanged more rapidly than in $150 \mathrm{~g}$ rats. The exchange of isotope from maternal plasma to fetal tissues was extremely slow.

\section{ZUSAMMENFASSUNG}

Der Austausch von radioaktivem Magnesium in den Geweben von Kuh, Kalb und Embryo.

Kälber und trächtige Kühe wurden mit Spurenmengen von radioaktivem Magnesium injiziert und daraufhin mit bestimmten Zeitabständen geschlachtet. Das Muster des intrazellularen Austausches vom Magnesium in den verschiedenen Geweben entsprach in grossen Zügen dem Muster, das für andere Tierarten rapportiert worden ist. Die Austauschgeschwindigkeit war jedoch viel langsamer als bei Ratten. Eine Ausnahme in dieser Hinsicht war, dass das Testismagnesium bei 6 Wochen alten Kälbern schneller ausgetauscht wurde als bei Ratten mit einem Gewicht von 150 g. Der Austausch des Magnesiums zwischen dem Blutplasma des Muttertieres und dem Gewebe des Embryos war sehr langsam.

\section{SAMMENDRAG}

Udvekslingen af radioaktivt magnesium $i$ vævene hos ko, kalv og foster.

En fors $\varnothing$ gsrække bestående af kalve og drægtige køer blev injiceret med spormængder af radioaktivt magnesium, og derefter slagtet med bestemte tidsintervaller. Mønstret for den intracellulære udveksling af magnesium $i$ de forskellige væv viste sig stort set at svare til det, som er rapporteret gældende for andre dyrearter. Udvekslingshastigheden var dog meget langsommere end hos rotter. En undtagelse i denne henseende er at testismagnesium hos 6 uger gamle kalve udveksledes hurtigere end hos rotter med en vægt på 150 g. - Udvekslingen af magnesium imellem moderplasma og fostervæv var yderst langsom. 